\title{
Chemical and Enzymatic Valorisation of Confectionery Waste into Biofuel: An Application of Circular Economy
}

\author{
Jorika Theart ${ }^{1}$, Sanette Marx ${ }^{1}$, Sanjib Kumar Karmee ${ }^{2 *}$
}

\begin{abstract}
${ }^{1}$ School of Chemical and Minerals Engineering, North-West University, Potchefstroom Campus, Private Bag X6001, Potchefstroom, 2520, SOUTH AFRICA ${ }^{2}$ Thermo-Chemical Conversion Division, Sardar Patel Renewable Energy Research Institute, Anand, Gujarat, INDIA

*Corresponding Author: sanjibkarmee@gmail.com
\end{abstract}

Citation: Theart, J., Marx, S. and Karmee, S. K. (2021). Chemical and Enzymatic Valorisation of Confectionery Waste into Biofuel: An Application of Circular Economy. European Journal of Sustainable Development Research, 5(1), em0146. https://doi.org/10.29333/ejosdr/9291

ARTICLE INFO

Received: 12 Mar. 2020

Accepted: 26 Aug. 2020

\begin{abstract}
Waste oil was extracted from lollipop effluent stream using a mixture of organic solvents viz. n-hexane and ethyl acetate. Lollipop effluent samples found to contain 10-18 wt.\% oil. Subsequently, the oil was subjected to biodiesel synthesis under solvent free condition using chemical and enzymatic catalysts. Among the base catalysts used, $\mathrm{KOH}$ catalyzed reaction gave highest biodiesel yield (99 \%) in 20 minutes. Furthermore, nine different lipases were screened as catalysts for biodiesel preparation from lollipop effluent oil. The screening experiments revealed that Novozyme- 435 was best among the lipases which gave $94 \%$ biodiesel in $18 \mathrm{~h}$ at $40{ }^{\circ} \mathrm{C}$.
\end{abstract}

Keywords: sustainability, circular economy, lollipop effluent, catalysts, biodiesel

\section{INTRODUCTION}

Confectionery industries contribute immensely towards global food supply (Henricus, 1980). These industries are major enterprises across the world and still expanding rapidly. Liquid and solid wastes generated from confectionery industries contain substantial amount of lipids and carbohydrates. These are non-edible in nature and needs to be managed from the circular economy perspective (Karmee, 2016a, 2016b, 2017, 2018a, 2018b; Karmee et al., 2015, 2018). Thus, these wastes can be valorised for biofuel production. In this context, majority of the world's energy needs are met by burning natural gas, petroleum based fuels and coal. This is leading to depletion of fossil fuels and simultaneously causing environmental degradation. Therefore, there is a need for development of alternative energy resources. In addition, energy starved nations are also exploring renewable energy sources as an option to become energy independent. Along this line, biofuels are extensively researched and recognized as a potential source of energy.

In the above context, biodiesel is a commercially available fuel primarily synthesized from fats, oils and greases. Thus far, industrial biodiesel production is largely focussed on use of many edible feedstocks. However, use of edible feedstocks is creating several challenges including food vs fuel debate. In addition, feedstocks are also increasing the biodiesel cost. To circumvent these limitations, non-edible waste feedstocks viz. food waste, sewage sludge and organic waste are currently employed as low-cost or no-value resources for biofuel production (Karmee and Chadha, 2005; Karmee and Lin, 2014). In line with this, confectionery products and their wastes contain oils, syrups, nuts, candied fruits and colour powders. Confectionery industrial effluent streams containing oils and carbohydrates can be directly valorised for bioenergy production (Figure 1).

In this paper, biodiesel was prepared from a lollipop effluent stream. In the initial stage, oil from lollipop effluent stream was extracted using $n$-hexane and ethyl acetate. Approximately, 10-18 wt.\% oil was recovered from lollipop effluent streams. Moisture from the obtained oil was removed using sodium sulphate $\left(\mathrm{Na}_{2} \mathrm{SO}_{4}\right)$. Subsequently, for biodiesel production chemical $\left(\mathrm{KOH}, \mathrm{CaO}\right.$ and $\left.\mathrm{Ca}(\mathrm{OH})_{2}\right)$ and biocatalysts (lipases) were used under solvent free condition. Biodiesel preparation via lipase catalysis is advantageous since it is substrate specific, moisture tolerant, recyclable and operates under mild experimental conditions (Karmee 2015, 2016a, 2016b, 2017). Initially, a series of commercially available lipases were screened for biodiesel production from confectionery waste oil. Immobilized lipase from Candida antartica lipase-B (CAL-B) was found to be suitable. Further optimization of reaction parameters were carried out using CAL-B. Key parameters including feedstock to alcohol molar ratio, temperature, and time course of reaction were optimised. Finally, reusability experiments for the Novozyme435 was performed. 


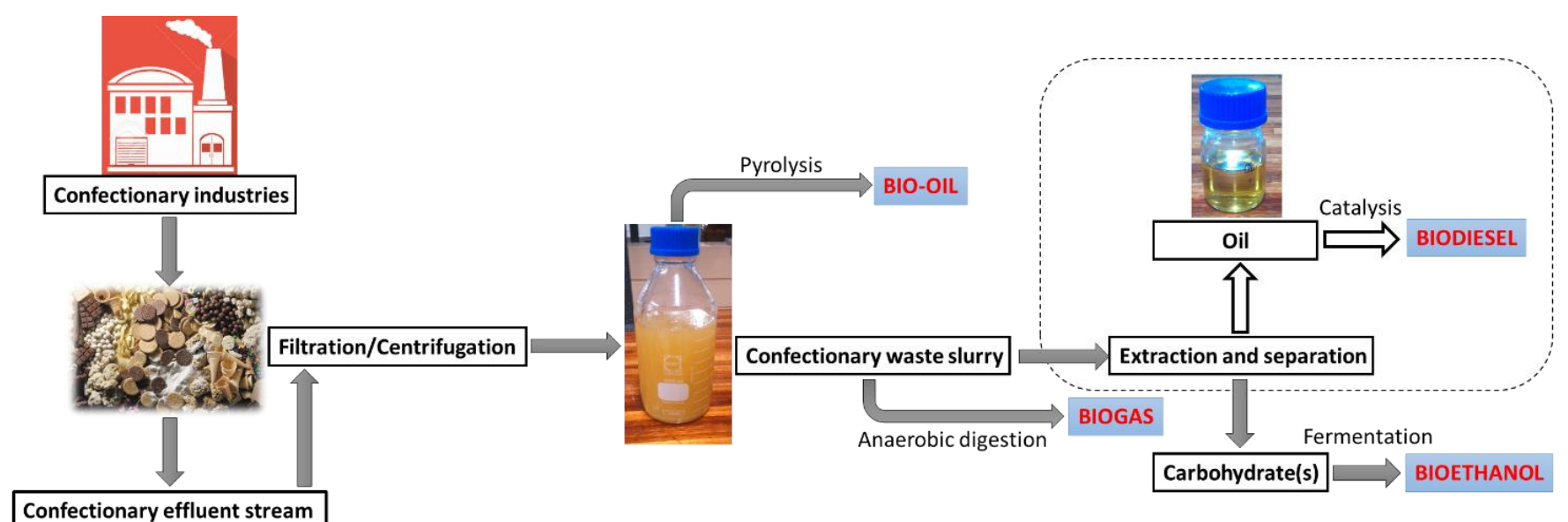

Figure 1. Plausible pathways for biofuel production from confectionery wastes

\section{METHODOLOGY}

\section{Enzymes, Chemicals and Instruments}

Feedstock used in this experiment was procured from a local lollipop unit located in North-West province, South Africa. $\mathrm{KOH}, \mathrm{CaO}, \mathrm{Ca}(\mathrm{OH})_{2}$, methanol, diethyl ether and deuterated chloroform $\left(\mathrm{CDCl}_{3}\right)$ of analytical grades were purchased from Sigma-Aldrich and Associated Chemical Enterprises (ACE), Johannesburg, South Africa. Mucor miehei, Pseudomonas cepacia, Rhizopus delemar, Geotrichum candidum, Candida rugosa, Caprica papaya, Porcine pancreas-II, Pseudomonas fluorescence and Candida antarctica lipase-B (Novozyme-435) lipases were obtained from Sigma-Aldrich, Amano Enzyme Inc., Nagoya, Japan and from local enzyme suppliers of South Africa. Waste oil to biodiesel conversion (\%) was calculated from ${ }^{1} \mathrm{H}$ NMR (Nuclear Magnetic Resonance) using a Bruker instrument (600 MHz) located at the Faculty of Natural Sciences, Laboratory for Analytical Services, North West University, Potchefstroom, South Africa.

\section{Preparation of Biodiesel from Lollipop Effluent Using Base Catalysts (KOH, $\mathrm{CaO}$ and $\mathrm{Ca}(\mathrm{OH})_{2}$}

A reaction mixture containing waste oil $(1 \mathrm{~g})$ and methanol $(480 \mu \mathrm{l})$ was prepared in a round bottom flask. To this mixture base catalyst ( 1 wt.\%) was added at $60^{\circ} \mathrm{C}$. The reaction was performed at 1:10 molar ratio of waste oil to methanol for 90 min. The reaction was monitored using ${ }^{1} \mathrm{H}$ NMR.

\section{Screening of Different Lipases for Biodiesel Production from Lollipop Effluent}

Nine lipases as stated in the earlier section were used during the screening experiments. For the screening experiments a molar ratio 1: 4 (oil to methanol) was used. The reaction mixture comprising methanol $(189 \mu \mathrm{l})$, oil $(1 \mathrm{~g})$ and lipase $(0.1 \mathrm{~g}, 10 \mathrm{wt} \%)$ was stirred at $40^{\circ} \mathrm{C}$ for $6 \mathrm{~h}$. After that, the mixture was diluted using diethyl ether $(2 \mathrm{ml} \mathrm{x} 2$ ). Subsequently, lipase was filtered and air dried. The biodiesel was placed in a $50 \mathrm{ml}$ round bottomed flask and dried at $70^{\circ} \mathrm{C}$ for 30 min under vacuum. The product was analyzed using ${ }^{1} \mathrm{H}$ NMR.

\section{Optimization of Feedstock to Alcohol Molar Ratio}

All experiments were started by addition of oil ( $1 \mathrm{~g})$ to Novozyme-435 (0.1 g, $10 \mathrm{wt} . \%)$. Then methanol of required molar ratios were added (1:1 (47 $\mu \mathrm{l}), 1: 3(146 \mu \mathrm{l}), 1: 4(189 \mu \mathrm{l})$, 1:5 (240 $\mu \mathrm{l}), 1: 6(285 \mu \mathrm{l}), 1: 8(379 \mu \mathrm{l}), 1: 10(480 \mu \mathrm{l})$ for optimization purpose at $40^{\circ} \mathrm{C}$. Each reactions were carried out for $6 \mathrm{~h}$. Downstream processing and ${ }^{1} \mathrm{H}$ NMR analysis were carried out as mentioned in the earlier section.

\section{Optimization of Reaction Temperature}

A moral ratio of 1:4 (oil to methanol) was used for the experiments, which consists of a mixture of methanol $(1: 4,189$ $\mu \mathrm{l})$, feedstock (1g) and biocatalyst (Novozyme-435) (0.1 g, 10 wt.\%). Reactions were performed at $30^{\circ} \mathrm{C}, 40^{\circ} \mathrm{C}, 50^{\circ} \mathrm{C}$ and $60^{\circ} \mathrm{C}$ to determine the maximum biodiesel yield. Each of these experiments was carried out for $6 \mathrm{~h}$.

\section{Two-step Methanol Addition Process for Biodiesel Production}

A two-step methanol addition process was followed to maximize the yield of biodiesel. The mixture was comprised of methanol $(1: 4,189 \mu \mathrm{l})$, oil $(1 \mathrm{~g})$ and biocatalyst $(0.1 \mathrm{~g}, 10 \mathrm{wt}$. $\%)$. The initial time duration was $6 \mathrm{~h}$ at $40^{\circ} \mathrm{C}$. Subsequently, after $6 \mathrm{~h}$ of duration an additional amount of methanol $(47 \mu \mathrm{l})$ was added to the reaction flask through septum. Further, the reaction was allowed to continue until $36 \mathrm{~h}$. All the obtained samples were analyzed using ${ }^{1} \mathrm{H}$ NMR to quantify the biodiesel.

\section{RESULTS AND DISCUSSION}

\section{Confectionary Waste Utilization}

Different solid and liquid effluents are generated in confectionery industries, which are known to contain organic substances (Beal and Raj, 2000; Das et al., 2013; El-Kassas et al., 2015; Lafitte-Trouque and Forster, 2000). These wastes are generally composed of biodegradable materials such as sugar, sweetener, casein, oil, milk, food colouring and flavouring agents. These are considered no-value resources as these are discarded without any further applications. Confectionery wastes can be converted into aquatic feeds, carbon richsources, bioenergy and value added products (Beal and Raj 
Table 1. Value added products from confectionery waste as compiled and reported by Johnstone-Robertson (2017)

\begin{tabular}{|c|c|c|}
\hline \multicolumn{3}{|l|}{ Solid waste } \\
\hline Source & Treatment technologies & Product (s) \\
\hline Confectionery waste & Biogas integrated gasification fuel cell & Electricity \\
\hline Confectionery waste & Microbial cultivation & Single cell protein (SCP) \\
\hline Confectionery waste products & Two-stage anaerobic digestion (AD) & Acetic acid, lactic acid, Ethanol and $\mathrm{CO}_{2}$ \\
\hline Flour waste streams & Batch fermentation & Bacterial cellulose \\
\hline Flour rich waste stream & Batch fermentation & Poly hydroxyl butyrate (PHB) \\
\hline Flour rich waste & Fed-Batch fermentation & Microbial lipid \\
\hline Sweets waste & Fuel cell & Electricity \\
\hline Waste wafer material & $\mathrm{AD}$ & Biogas and digestate \\
\hline \multicolumn{3}{|l|}{ Liquid waste } \\
\hline Source & Treatment technologies & Product (s) \\
\hline Confectionery factory effluent & Shake flask & Algal biomass \\
\hline Confectionery waste water & Sludge waste water treatment plant & Water for irrigation \\
\hline Confectionery waste water & Aerobic conditions & Xanthan gum \\
\hline Confectionery waste water & $\begin{array}{l}\text { Anaerobic digestion (AD) with enrich } \\
\mathrm{H}_{2} \text { producing bacteria (Methanogens inactive) }\end{array}$ & $\mathrm{H}_{2}$ \\
\hline Chocolate waste water & Microbial fuel cells & Electricity \\
\hline Chocolate waste water & $\mathrm{AD}$ & Electricity \\
\hline Chocolate soup & $\mathrm{AD}$ & Electricity \\
\hline Candied jujube waste water & Batch fermentation & Bacterial cellulose \\
\hline Confectionery waste water & Fermentation & Bioflocculant \\
\hline Confectionery waste water & Sloping pilot plant & $\begin{array}{l}\text { Microalgae biomass, enzymatic and non-enzymatic } \\
\text { antioxidant }\end{array}$ \\
\hline Chocolate waste water & $\mathrm{AD}$ & Electricity \\
\hline (Containing sugar syrups) & Dual anaerobic co-digestion & $\mathrm{CH}_{4}$ \\
\hline Chocolate waste water & $\mathrm{AD}$ & Biogas and COD reduction \\
\hline Confectionery waste water & Anaerobic pretreatment and aerobic treatment & $\mathrm{CH}_{4}$ and reduced COD levels and water for irrigation \\
\hline Confectionery waste water & Sequential two-stage anaerobic treatment & Decrease in COD levels \\
\hline Confectionery waste water & Fermentation & Clean water with reduced COD, BOD, FOG, TSS, and odors. \\
\hline Confectionery waste water & Aerobic treatment using trickling filter & Decrease in COD levels \\
\hline
\end{tabular}

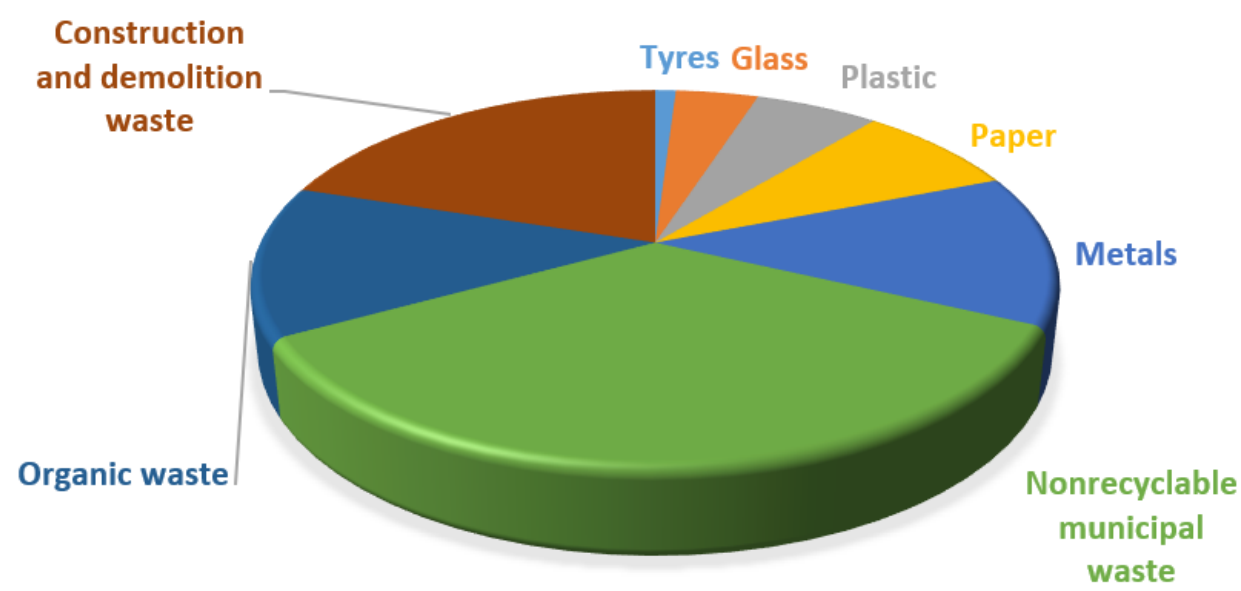

Figure 2. Distribution of different types of wastes generated in South Africa (Ekelund and Nyström, 2007; Environment outlook, 2013; NOWCS South Africa, 2013)

2000; Das et al., 2013; El-Kassas et al., 2015; Lafitte-Trouque and Forster, 2000). In this context, South Africa, has many confectionery industries such as lollipop factories that produce sizeable quantities of wastes, which can be valorised into biofuels, chemicals and biopolymer (García et al., 2011; Genc and Ozbay, 2015; Gough et al., 2013; JohnstoneRobertson, 2017; Lunghi and Burzacca, 2004; Pilarska et al., 2019; Ranade et al., 1989; Ruggeri et al., 2013; Tsakona et al., 2016) (Table 1). Similarly, using advanced valorisation technologies the $\sim 13 \%$ organic waste generated in South Africa can be converted into biofuels, chemicals, materials and other high value products (Ekelund and Nyström 2007;
NOWCS South Africa 2013; Environment outlook 2013). (Figure 2). Environmental friendly management of confectionery wastes is significant from waste management and circular economy context (Miah et al., 2018) (Figure 3).

\section{Biodiesel Production from Lollipop Effluent via Base Catalysis}

Food industries generate significant amounts of waste during processing, production, packaging, and storage (Sohair et al., 2008). South Africa generates large quantities of organic food wastes which needs technical valorisation (Greben and Oelofse, 2009; Oelofse and Nahman, 2013). During the course 


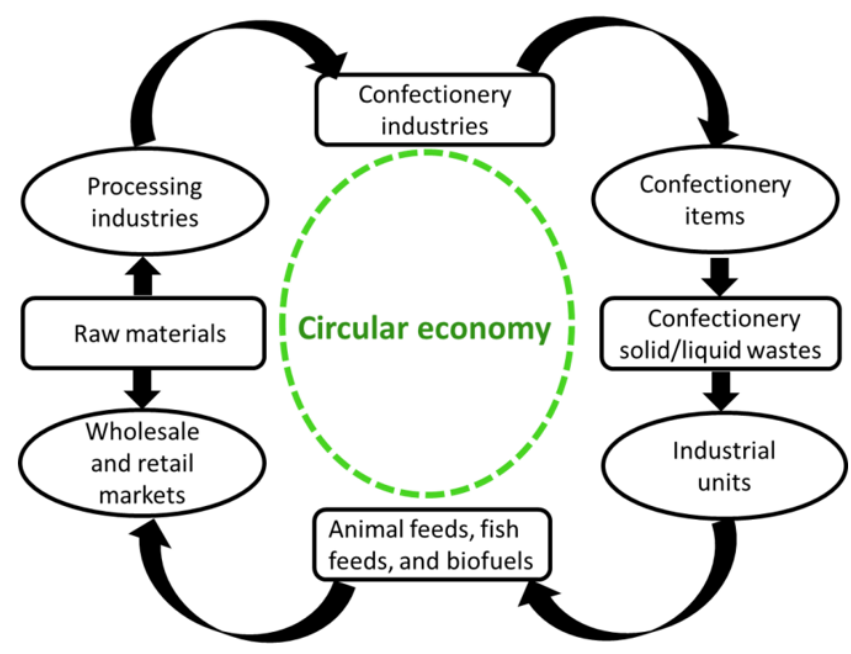

Figure 3. A circular economy approach for valorisation of confectionary waste into biofuels and value added products

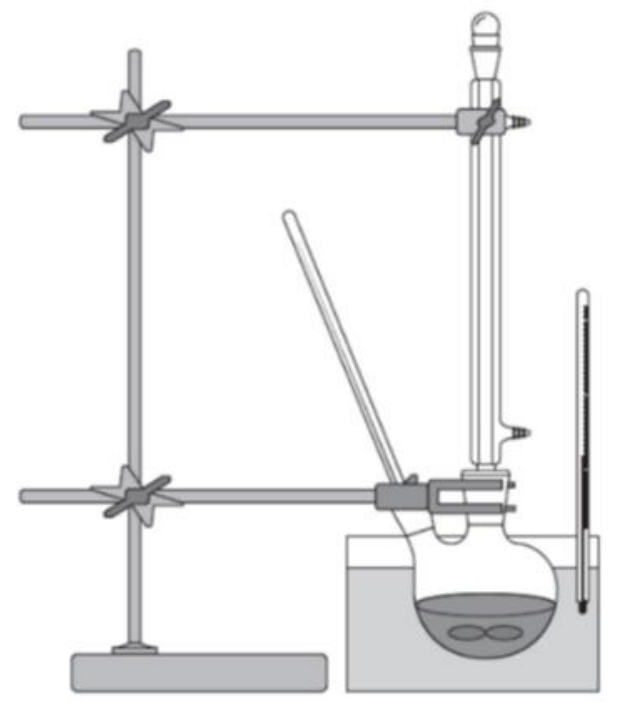

Figure 4. Experimental set-up for biodiesel preparation from confectionery waste

of this work, lollipop industry waste stream was valorised for biofuel production. Initially oil from the lollipop effluent was extracted using $n$-hexane and ethyl acetate $(95 \mathrm{v}: 5 \mathrm{v})$ as a solvent. Up to $10-18$ wt.\% of oil was recovered from confectionery waste samples. After extraction, the recovered oily portions were combined and concentrated via a roatary evaporator. To remove trace amount of moisture in the oily fraction it was dried over sodium sulphate and stored for further use.

The waste oil isolated from the lollipop effluent was subjected to base catalysed biodiesel preparation. The $\mathrm{KOH}$, $\mathrm{CaO}$ and $\mathrm{Ca}(\mathrm{OH})_{2}$ catalysed (1 wt. \%) reactions were performed at $1: 10$ molar ratio of waste oil to alcohol at $60{ }^{\circ} \mathrm{C}$ in a two necked round bottom flask equipped with heating bath, condenser and magnetic stirrer (Figure 4). Among all base catalysts, high conversion (99\%) of biodiesel was observed in 20 min during $\mathrm{KOH}$ catalysed reaction (Figure 5).

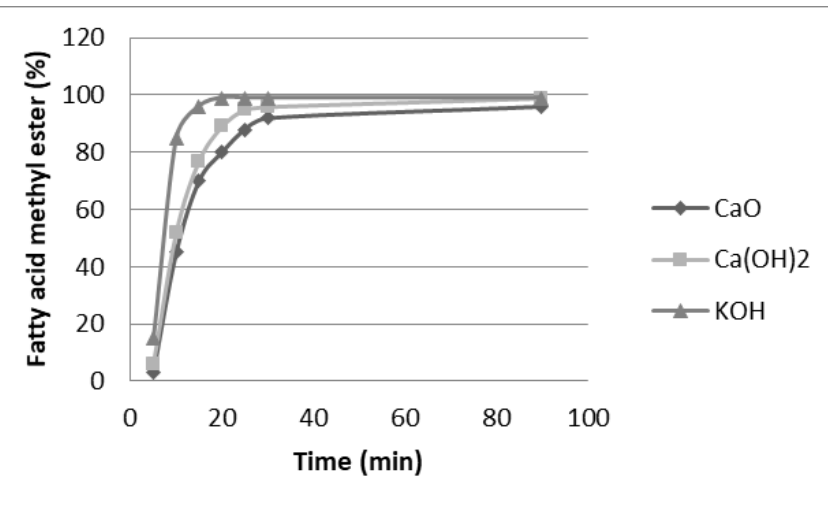

Figure 5. Base catalysed production of biodiesel from confectionery waste

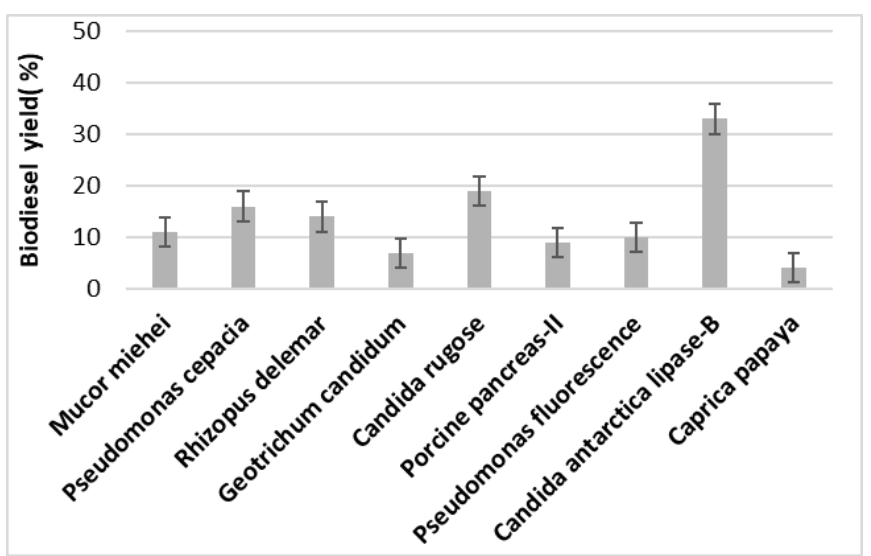

Figure 6. Potential of lipases for biodiesel production from confectionery waste oil

\section{Biodiesel Production from Lollipop Effluent Using Lipases}

Lipases are widely used enzymes for applications in energy, food, beverage, detergent, leather, pharmaceutical and paper industries. Under physiological conditions, lipases catalyse hydrolysis of triglycerides to glycerol and free fatty acids. However, in non-conventional media lipase catalyses esterification and transesterification reaction. As mentioned in Figure 6, nine different lipases were screened for biodiesel production from waste oil derived from lollipop effluent stream. The biodiesel yield was in the range of $4-34 \%$ (Figure 6). During screening it was observed that Candida antarctica lipase-B (Novozyme-435) gave 34\% biodiesel yield (Figure 6).

Novozyme-435 was applied for further optimization of reaction conditions. The time course study of biocatalytic biodiesel production was carried out for $36 \mathrm{~h}$. However, at 18 h, a maximum 94\% biodiesel yield was achieved (Figure 7). Therefore, $18 \mathrm{~h}$ is considered to be the optimum reaction time. The reusability of the biocatalyst (Novozyme-435) was studied at $1: 5$ molar ratio and $40{ }^{\circ} \mathrm{C}$. It was found that, after $14^{\text {th }}$ reaction cycle, $72 \%$ biodiesel yield was obtained. Around $24 \%$ decrease in biodiesel yield was observed after the $14^{\text {th }}$ reaction cycle (Figure 8).

Base catalysed reaction is faster as compared to the enzyme catalysed reactions. During base catalysis methoxide is formed; whereas, during lipase catalysed reaction enzyme- 


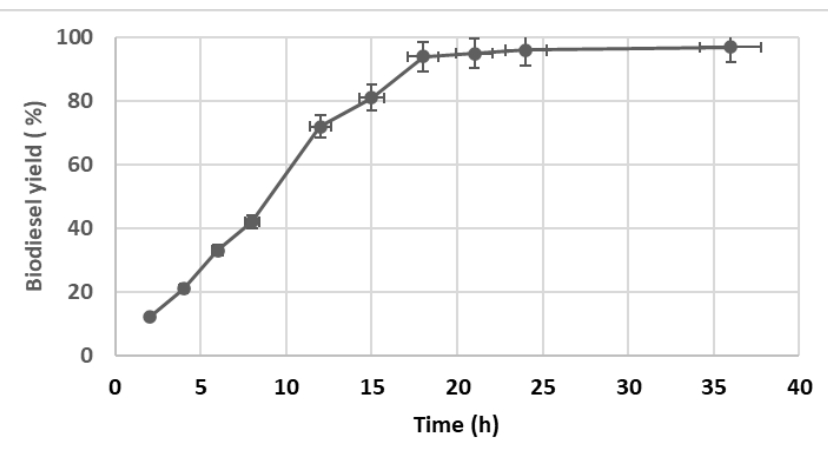

Figure 7. Reaction kinetics of Novozyme-435 catalysed biodiesel production from confectionery waste

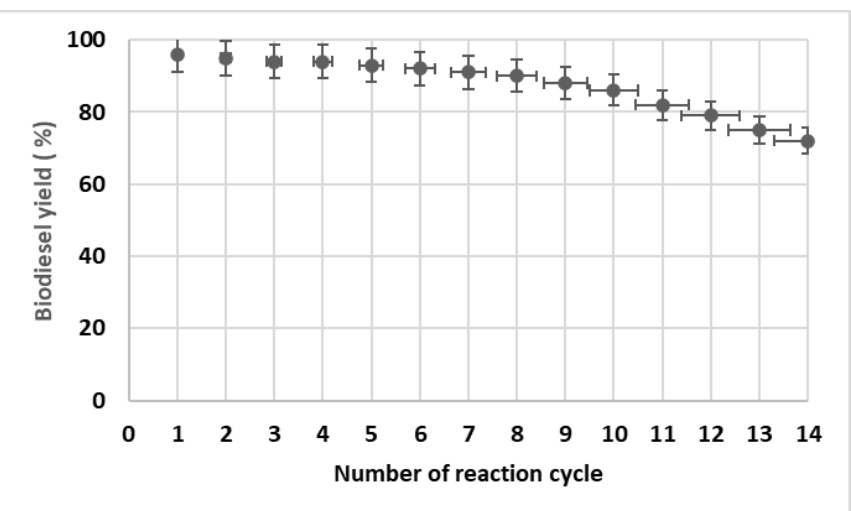

Figure 8. The reusability of Novozyme-435 during biodiesel preparation

substrate complex is formed. For the base catalysed reaction optimum conditions are: 1:10 molar ratio (substrate to alcohol), $60{ }^{\circ} \mathrm{C}$ and $20 \mathrm{~min}$ (reaction time). In contrast, for the lipase catalysed reaction, optimum conditions are: 1:5 molar ratio (substrate to alcohol), $40{ }^{\circ} \mathrm{C}$ and $18 \mathrm{~h}$.

\section{CONCLUSIONS}

Liquid effluents from confectionery industries are potential feedstocks for biofuel production. In this work, both chemical (base) and biocatalysts (lipases) were used for biodiesel preparation from confectionery waste oil. $\mathrm{KOH}$ gave 99\% biodiesel yield in $20 \mathrm{~min}$; whereas, Novozyme-435 catalyzed reaction produced $94 \%$ biodiesel in $18 \mathrm{~h}$.

\section{ACKNOWLEDGEMENTS}

The authors are grateful to the North-West University, Potchefstroom, South Africa for financial support. All the experimental work and writing of manuscript were done at the North-West University, Potchefstroom. Dr Karmee is thankful to the Sardar Patel Renewable Energy Research Institute (SPRERI), Gujarat, India for providing infrastructure to complete the revision of this manuscript as per recommendations of the reviewers and the editor.

\section{REFERENCES}

Beal, L. J. and Raj, R. D. (2000). Sequential two-stage anaerobic treatment of confectionery wastewater. Journal of Agricultural Engineering Research, 76, 211-217. https://doi.org/10.1006/jaer.2000.0555

Das, B. K., Gauri, S. S. and Bhattacharya, J. (2013). Sweetmeat waste fractions as suitable organic carbon source for biological sulfate reduction. International Biodeterioration \& Biodegradation, 82, 215-223. https://doi.org/10.1016/ j.ibiod.2013.03.027

Ekelund, L. and Nyström, K. (2007). Composting of municipal waste in South Africa -sustainability aspects. Uppsala University, Sweden. Retrieved from https://www.utn.uu.se/ sts/student/wp-content/uploads/gamla\%20exjobb/0602_ kristinanystromlottenekelund.pdf (Accessed: 11 March 2020).

El-Kassas, H. Y., Heneash, A. M. M. and Hussein, N. R. (2015). Cultivation of Arthrospira (Spirulina) platensis using confectionary wastes for aquaculture feeding. Journal of Genetic Engineering and Biotechnology, 13(2), 145-155. https://doi.org/10.1016/j.jgeb.2015.08.003

Environment outlook: Chapter 13, Waste management, South Africa. (2013). Retrieved from https://www.environment. gov.za/sites/default/files/reports/environmentoutlook_ch apter13.pdf (Accessed: 11 March 2020).

García, I. L., Dorado Pérez, M. P., López, J. A., Villar, M. A., Yanniotis, S. and Koutinas, A. (2011). Valorisation of confectionary industry wastes for the microbial production of polyxydroxyalkanoates. International Congress on Engineering and Food, Food process engineering in a changing world, vol. II, 745-746, Atenas, Greece, 22-26.

Genc, N. and Ozbay, I. (2015). Fermentative hydrogen production in batch experiments using molasses, potato processing industry wastewater and chocolate waste: influence of acidic hydrolyzation. Asian Journal of Chemistry, 27(6), 2184-2188. https://doi.org/10.14233/ ajchem.2015.18059

Gough, H. L., Nelsen, D., Muller. C. and Ferguson, J. (2013). Enhanced methane generation during thermophilic codigestion of confectionary waste and grease-trap fats and oils with municipal wastewater sludge. Water Environment Research, 85(2), 175-183. https://doi.org/ 10.2175/106143012X13418552642128

Greben, H. A. and Oelofse, S. H. H. (2009). Unlocking the resource potential of organic waste: a South African perspective. Waste Management \& Research, 27(7), 676684. https://doi.org/10.1177/0734242X09103817

Henricus, A. J. M. D. (1980). Method for making confectionery lollipops. US 4208437, Application number, US 05/930,122.

Johnstone-Robertson, M. (2017). Value recovery from confectionery waste. Retrieved from https://www.wastero admap.co.za/download/ims2017_foodwaste_present15.pdf (Accessed: 11 March 2020). 
Karmee, S. K. (2015). Lipase catalyzed synthesis of fatty acid methyl esters from crude Pongamia oil. Energy Sources Part A., 37, 536-542. https://doi.org/10.1080/15567036.2011. 572131

Karmee, S. K. (2016a). Liquid biofuels from food waste: current trends, prospect and limitation. Renew Sustain Energy Rev 53, 945-953. https://doi.org/10.1016/j.rser.2015.09.041

Karmee, S. K. (2016b). Preparation of biodiesel from nonedible plant oils using a mixture of used lipases. Energy Sources Part A, 38(18), 2727-2733. https://doi.org/10.1080/ 15567036.2015.1098748

Karmee, S. K. (2018a). A spent coffee grounds based biorefinery for the production of biofuels, biopolymers, antioxidants and biocomposites. Waste Management, 72, 240-254. https://doi.org/10.1016/j.wasman.2017.10.042

Karmee, S. K. (2018b). Enzymatic biodiesel production from Manilkara Zapota (L.) seed oil. Waste Biomass Valorization, 9, 725-730. https://doi.org/10.1007/s12649-017-9854-8

Karmee, S. K. (2020). Technical valorisation of spent coffee grounds and food waste using sulfuric acid immobilized on silica. Biofuels, 11(2), 155-161. https://doi.org/10.1080/ 17597269.2017.1378989

Karmee, S. K. and Chadha, A. (2005). Preparation of biodiesel from crude oil of Pongamia pinnata. Bioresour Technol, 96, 1425-1429. https://doi.org/10.1016/j.biortech.2004.12.011

Karmee, S. K. and Lin, C. S. K. (2014). Lipids from food waste as feedstock for biodiesel production: Case Hong Kong. Lipid Technol, 26, 206-209. https://doi.org/10.1002/ lite.201400044

Karmee, S. K., Linardi, D., Lee, J. and Lin, C. S. K. (2015). Conversion of lipid from food waste to biodiesel. Waste Manage, 41, 169-173. https://doi.org/10.1016/j.wasman. 2015.03.025

Karmee, S. K., Wian, S. and Marx, S. (2018). Biofuel production from spent coffee grounds via lipase catalysis. Energy Sources Part A, 40(3), 294-300. https://doi.org/10.1080/ 15567036.2017.1415394

Lafitte-Trouque, S. and Forster, C. F. (2000). Dual anaerobic co-digestion of sewage sludge and confectionery waste. Bioresour Technol., 71, 77-82. https://doi.org/10.1016/ S0960-8524(99)00043-7
Lunghi, P. and Burzacca, R. (2004). Energy recovery from industrial waste of a confectionery plant by means of BIGFC plant. Energy, 29(12-15), 2601-2617. https://doi.org/10.1016/j.energy.2004.05.016

Miah, J. H., Griffiths, A., McNeill, R., Halvorson, S., Schenker, U., Espinoza-Orias, N. D., Morse, S., Yang, A. and Sadhukhan, J. (2018). Environmental management of confectionery products: Life cycle impacts and improvement strategies. J. Clean. Prod., 177(10), 732-751. https://doi.org/10.1016/j.jclepro.2017.12.073

NOWCS, The national organic waste composting strategy, South Africa. (2013). http://sawic.environment.gov.za/ documents/1825.pdf (Accessed: 10 March 2020).

Oelofse, S. H. H. and Nahman, A. (2013). Estimating the magnitude of food waste generated in South Africa. Waste Manag Res., 31(1), 80-86. https://doi.org/10.1177/ $0734242 X 12457117$

Pilarska, A. A., Pilarski, K., Wolna-Maruwka, A., Boniecki, P. and Zaborowicz, M. (2019). Use of confectionery waste in biogas production by the anaerobic digestion process. Molecules, 24(1), 37. https://doi.org/10.3390/ molecules 24010037

Ranade, D. R., Yeole, T. Y., Meher, K. K., Gadre, R. V. and Godbole, S. H. (1989). Biogas from solid waste originated during biscuit and chocolate production: a preliminary study. Bioresour Technol, 28(2), 157-161. https://doi.org/10.1016/0269-7483(89)90079-7

Ruggeri, B., Luongo Malave, A. C., Bernardi, M. and Fino, D. (2013). Energy efficacy used to score organic refuse pretreatment processes for hydrogen anaerobic production. Waste Manage, 33(11), 2225-2233. https://doi.org/10.1016/j.wasman.2013.06.024

Sohair, I. A., Fayza, A. N. and Saber, A. E. (2008) Wastewater management in small- and medium-size enterprises: case studies. Environmentalist, 28, 289-296. https://doi.org/ 10.1007/s10669-007-9142-4

Tsakona, S., Skiadaresis, A. G., Kopsahelis, N., Chatzifragkou, A., Papanikolaou, S., Kookos, I. K. and Koutinas, A. A. (2016). Valorisation of side streams from wheat milling and confectionery industries for consolidated production and extraction of microbial lipids. Food Chem., 198, 85-92. https://doi.org/10.1016/j.foodchem.2015.11.031 